\title{
Y-Chromosome Microdeletion Analysis in Infertile Men from Upper Egypt
}

\author{
Kamal Z. Shaeer, MD*; Essam Nada, MD**; Ramadan Saleh, MD**; Manal O. \\ El Hamshary, PhD***; Ashraf A. Abd El-Latif, MSc**. \\ * Department of Andrology, Sexology and STDs- Faculty of Medicine- Cairo \\ University; ** Department of Dermatology, Venereology and Andrology- Faculty of \\ Medicine- Sohag University;*** Department of Molecular Diagnostics and \\ Therapeutics- Genetic Engineering and Biotechnology Research Institute- Sadat City \\ University.
}

\begin{abstract}
Objectives:To study the prevalence and patterns of Y-chromosome microdeletions in infertile men from Upper Egypt and to determine the relationship between Ychromosome microdeletions with clinicaland laboratoryfindings in these patients.

Design: Cross-sectionalstudy.

Patients: Infertile men $(n=210)$ and a control group of fertile men with normal semen analysis $(n=30)$.

Methods: Clinical evaluation, standard semen analysis according to the WHO guidelines (WHO, 2010) andserum levels of reproductive hormones were evaluated. Multiplex PCR was done for detection of Y chromosome microdeletions.

Results:AZF deletions were present in $7.14 \%$ of infertile men $(9.59 \%$ in azoospermic and $1.56 \%$ in oligo-zoospermic men) with no deletions in the fertile normo-zoosperic men.CompleteAZFc was the detected in $2.05 \%$ of azoospermic men.Partial AZFc deletions were found in $5.7 \%$ of infertile men, with $\mathrm{gr} / \mathrm{gr}$ deletion in $5.24 \%$ and b2/b3 deletion in $0.48 \%$. There was no significant difference between patients with AZF deletions and azoospermic men without deletions as regards testicular volume and serum levels of FSH, LH, testosterone and prolactin.

Conclusions:Microdeletions of Y chromosome may play a role in pathogenesis of non-obstructive azoospermia. The testicular volumes as well as levels of FSH, LH, testosterone and prolactin were not correlated with the finding of $\mathrm{Y}$ chromosome microdeletions.
\end{abstract}

Key words: male infertility, Y chromosome microdeletion, AZF regions.

\section{INTRODUCTION}

Infertility is defined as the failure to achieve a clinical pregnancy after 12 months or more of regular unprotected sexual intercourse ${ }^{(\mathbf{1})}$. It affects approximately $10-15 \%$ of couples, even up to $30 \%$ in some regions of the world $^{(2)}$. Male infertility contributes to more than half of all cases of global childlessness ${ }^{(3)}$. At least $15 \%$ of cases with male infertility are related to genetic disorders, including both chromosomal and single-gene alterations $^{(4)}$.

Microdeletions of Y chromosome are the second most frequent genetic cause of male infertility after Klinefelter syndrome $^{(5)}$.A region on the long arm of the $\mathrm{Y}$ chromosome has been identified as the

"Azoospermia Factor" and is subdivided into three regions, $\mathrm{AZFa}, \mathrm{AZFb}$, and $\mathrm{AZFc}^{(6)}$. Microdeletions of AZF regions are related to spermatogenic failure ${ }^{(7)}$. The overall frequency of $\mathrm{Y}$ chromosome microdeletions varies from 1 to $55 \%$ in the different published studies ${ }^{(8-10)}$. The most frequent deletion type is the AZFc region deletion (approximately 80\%) followed by AZFa (0.5-5\%), AZFb (1$4 \%)$ and AZFbc (1-3\%) deletion ${ }^{(11)}$. 
Partial AZFc deletions were identified, with $\mathrm{gr} / \mathrm{gr}$ deletion as the most common, followed by $b 2 / b 3$ and $b 1 / b 3^{(\mathbf{1 2})}$. Although $\mathrm{gr} / \mathrm{gr}$ deletion removes half of the AZFc gene content, its clinical significance is still a matter of debate, because carriers may exhibit highly variable spermatogenic phenotypes ranging from azoo- to normozoospermia. Clearly the effect of the deletion is largely dependent on the ethnic and geographic origin of the study population ${ }^{(11)}$.

In Egypt; examination of $\mathrm{Yq}$ microdeletions in only 33 infertile males with undetectable chromosomal anomalies revealed microdeletions in four men $(12 \%)$; with two patients had deletions at $\mathrm{AZFc}$, one at $\mathrm{AZFa}$ and last one had microdeletion at almost the entire AZF region ${ }^{(13)}$. Another study carried out in 2010 on 49 patients (28 with azoospermia and 21 with severe oligospermia) reported microdeletions in 24 patients (37\%) and the highest frequency of microdeletions was in the $\mathrm{AZFb}$ locus (66.7\%), followed by the AZFa locus (20.8\%) and then the AZFc locus $(12.5 \%)^{(\mathbf{1 4})}$.

Microdeletions were reported in $20.4 \%$ (11/54) of azoospermic men with 10 patients $(90.9 \%)$ having AZFc deletion and one case $(9.1 \%)$ had partial $\mathrm{AZFa}+\mathrm{b}$ deletion. Among the 10 cases who had AZFc deletions, five cases had gr/gr subtype $(50 \%)$, and the other 5 cases had b2/b4 subtype (15). Another study found Y-chromosome microdeletions in $10.3 \%$ $(11 / 107)$ of azoospermic patients and the highest frequency of microdeletions was in the AZFc locus, followed by the $\mathrm{AZFb}$ and the AZFa loci ${ }^{(16)}$.

Identification of a particular AZF deletion can provide valuable prognostic information. Complete deletions of the $\mathrm{AZFa}$ or $\mathrm{AZFb}$ regions indicate that sperm will not be found at the time of testicular sperm extraction (TESE), whereas deletions in AZFc indicated a $50 \%$ likelihood of finding sperm on
microTESE $^{(7)}$. Testing of $\mathrm{Yq}$ microdeletions is also an essential prerequisite for infertile men undergoing intra-cytoplasmic sperm injection to rule out the possibility of transmission of the same deletions to their male offspring, who could also experience infertility ${ }^{(17)}$. The objectives of this study were to:(1) explore the patterns of Y-chromosome microdeletions in infertile men from Upper Egypt, and(2) determine the relationship between Y-chromosome microdeletions with clinical, laboratory and histopathological findings in these patients.

\section{PATIENTS AND METHODS:}

This cross-sectional, study included 210 infertile men attending Andrology clinic at Sohag University Hospitals.A group of 30 fertile men with history of having at least one child in the last 2 years and normal semen analysis was included as a control.The study was approved by Ethical and Research committees at Sohag Faculty of Medicine. An informed consent was obtained from all participants.

\section{Exclusion criteria:}

Patients with evidence of obstruction of seminal tract.

" Patients with evident varicocele.

" Patients with defective spermatogenesis secondary to genital infection, trauma or torsion.

" Patients with history of testicular maldescent.

" Patients having numerical chromosomal anomalies.

" Patients who were treated with chemotherapeutic agents or radiotherapy. Methods: Patients were evaluated as follow:

I- Initial evaluation:Personal data (age, residency, occupation and special habits) were obtained from all participants. Marital and sexual histories were obtained from all participants. The family history, including data on the fertility status of parents, and relatives was reported. 
General examination was done to detecteunuchoidal features. Careful genital examination was performed to detect abnormality of penis, testes or epididymis. The spermatic cord was examinedfor presence of vas, nodularity or varicocele.

\section{II- Laboratory investigations:}

\section{1) Semen analysis:}

Semen analysis was performed according to World Health Organization 2010 guidelines $^{(\mathbf{1 8})}$. According to sperm concentration, participants were classified into three categories: normozospermic $(\geq 15$ millions $/ \mathrm{ml})$, oligozospermic (<15 millions/ml), or azoospermic (complete absence of spermatozoa even after centrifugation at $3000 \mathrm{~g}$ for 15 minutes for at least 2 times, 2 weeks apart).

\section{2) Hormonal profile:}

Four ml of venous blood of the patient was drawn from the cubital vein in the morning from 08.00 a.m. to 10.30 a.m. and was incubated at $37^{\circ} \mathrm{C}$ water bath for 10 minutes, and centrifuged at $3000 \mathrm{~g}$ for 10 minutes. Serum levels of follicle stimulating hormone (FSH), luteinizing hormone $(\mathrm{LH})$, total testosterone and prolactin were measured using an enzyme linked fluorescent immunoassay with a mini-VIDAS device (BioMERIEUX SA). The normal male reference ranges for these hormones were: FSH (1.7-12.0 mIU/ml), LH (1.1$7.0 \mathrm{mIU} / \mathrm{ml})$, total testosterone (3.0-10.6 $\mathrm{ng} / \mathrm{ml})$ and prolactin $(3.0-25.0 \mathrm{ng} / \mathrm{ml})$.

3) Y-chromosome microdeletion analysis:

\section{1- DNA Extraction:}

Genomic DNA was extracted from peripheral leukocytes collected from a venous blood sample. TheDNA was extracted using the wizard genomic DNA purification kit according to the manufacturer's instructions.

\section{2- DNA Amplification:}

Polymerase chain reaction (PCR) was done on MJ-research-100 machine. The long arm of the $\mathrm{Y}$ chromosome DNA was subjected to PCR using 8 sets of $\mathrm{Y}$ specific sequence tagged sites (STSs). A two-step approach was employed to identify the partial AZFc deletions. First screening was performed using six pairs of primers to screen and exclude large deletions of the AZF region (AZFa, $\mathrm{AZFb}, \mathrm{AZFc}$ ) according to the European Academy of Andrology and the European Molecular Genetics Quality Network (EAA/EMQN) 2014 guidelines $^{(\mathbf{1 1})}$. These STSs were: sY84 and sY86 for AZFa; sY127 and sY134 $\mathrm{AZFb}$; and sY254 and sY255 for AZFc. Second step amplification was performed to screen for partial deletions of AZFc region using STSs: sY1191 (specific for the gr/gr-g1/g2 and b1/b3 deletions) and sY1291 (specific for the b2/b3 and gr/gr-g1/g3 deletions) ${ }^{(\mathbf{1 2})}$. The diagnosis of $\mathrm{gr} / \mathrm{gr}$ deletion was based on the absence of marker sY1291 and presence of sY1191; while the absence of sY1191 and presence of sY1291 represented b2/b3 deletion ${ }^{(11)}$.

Single PCR technique was performed. In the case of the absence of any marker the PCR was repeated two times at the same annealing temperature and two times at lower annealing temperature and an internal control (SRY marker) to confirm the deletion and to role out false negative PCR result.A $2.0 \mu \mathrm{l}(50 \mathrm{ng})$ aliquot of the genomic DNA was amplified by PCR, in a total volume of 12 ul using PCR master mix from Promega, USA. The PCR was carried out according to the following protocol: 36 cycles at $94^{\circ} \mathrm{C}$ for $30 \mathrm{~s}, 60^{\circ} \mathrm{C}$ for $50 \mathrm{~s}$ and $72^{\circ} \mathrm{C}$ for $60 \mathrm{~s}$. The program was preceded by a $4 \mathrm{~min}$ denaturation step at $95^{\circ} \mathrm{C}$ and followed by a final extension step at $72^{\circ} \mathrm{C}$ for 5 min. In situations of absent PCR product, the reaction was repeated at $55^{\circ} \mathrm{C}$ annealing temperature with enternal control (SRY) to role out false results.

\section{3- Visualization of PCR products:}

Visualization of PCR products was performed by running the samples against a $1 \mathrm{~kb}$ DNA ladder (Promega; 
USA) as a marker on a $2 \%$ agarose gel stained with ethidium bromide $0.5 \mathrm{mg} / \mathrm{ml}$. In all amplification reactions, a female DNA and a water sample (with no template) were included as negative controls. As a positive control, a male DNA previously proved positive for all the markers was included in the amplification reaction. The PCR data was compared to the latest $\mathrm{Y}$ chromosome map reported $^{(\mathbf{6}, \mathbf{1 2})}$.

\section{4- Reagents preparartion:}

3.4.1- PCR buffer:10X PCR buffer contains: 10 mMTris-HCL pH8.3; 1.5 $\mathrm{mM} \mathrm{MgCl} 2 ; 50 \mathrm{mMKCl}$.

3.4.2- Tris-acetate-EDTA (TAE) Electrophoresis buffer: $1 \mathrm{X}=40$ mMTris base, $40 \mathrm{mM}$ acetic acid, $1 \mathrm{mM}$ EDTA (ethylenediaminetetraacetate).
3.4.3- Loading buffer: 0.5 gmbromophenol blue, $40 \%$ sucrose, up to $100 \mathrm{ml}$ water.

3.4.4- Ethidium Bromide satain:Stock solution of $0.5 \mathrm{gm} / \mathrm{ml}$ is prepared. Final concentration included in agarose gel is 0.1 to $0.5 \mathrm{ug} / \mathrm{ml}$.

\section{Statistical analysis:}

Data were analyzed using Statistical Package for Social Sciences soft ware program (SPSS, version 24). Qualitative variables were recorded as frequencies and percentages and were compared by chi-square test. Quantitative variables were presented as means \pm standard deviation (SD) and were compared by independent t-test. $\mathrm{P}$ value $<0.05$ was considered statistically significant.

\section{RESULTS}

The study populations were classified according to sperm concentration into 3 groups: azoospermia $(n=146)$, oligozoospermia $(n=64)$ and fertile normozoospermic men $(\mathrm{n}=30)$.

\section{Demographic data:}

The mean age \pm SD of the infertile patients was $34.12 \pm 5.95$ years, with $105(50 \%)$ of them from urban areas and $76(36.2 \%)$ of them were smokers. The mean duration of marriage \pm SD of theinfertile patientswas $5.40 \pm 3.96$ years. Family history of infertility was positive in $14(6.7 \%)$ of the infertile patients. The demographic data of the infertile men groups as well as control group are shown in table 1.

Table 1: Demographic data in the study population.

\begin{tabular}{|c|c|c|c|c|c|c|c|c|c|}
\hline \multicolumn{2}{|l|}{ Item } & 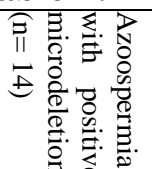 & 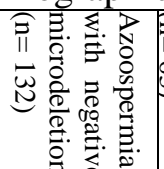 & 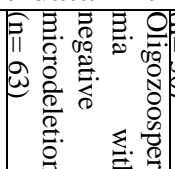 & 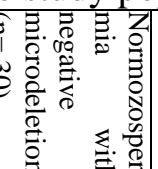 & 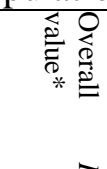 & $P 1$ & $P 2$ & $P 3$ \\
\hline \multicolumn{2}{|c|}{ Age (years) } & $36.6 \pm 5.9$ & $34.2 \pm 6.5$ & $33.6 \pm 5.4$ & $33.4 \pm 3.2$ & 0.11 & 0.17 & 0.10 & 0.09 \\
\hline \multirow{2}{*}{ 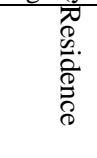 } & Urban & $\begin{array}{l}6 \\
(43 \%)\end{array}$ & $\begin{array}{l}69 \\
(52.3 \%)\end{array}$ & $\begin{array}{l}30 \\
(47.6 \%)\end{array}$ & $\begin{array}{l}18 \\
(60 \%)\end{array}$ & \multirow{2}{*}{0.56} & \multirow{2}{*}{0.51} & \multirow{2}{*}{0.75} & \multirow{2}{*}{0.29} \\
\hline & Rural & $\begin{array}{l}8 \\
(57 \%)\end{array}$ & $63(47.7 \%)$ & $33(52.4 \%)$ & $\begin{array}{l}12 \\
(40 \%)\end{array}$ & & & & \\
\hline \multirow{4}{*}{ 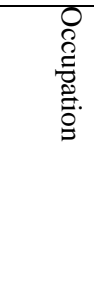 } & Employe & $\begin{array}{l}2 \\
(14.3 \%) \\
\end{array}$ & $\begin{array}{l}30 \\
(22.7 \%) \\
\end{array}$ & $\begin{array}{l}23 \\
(36.5 \%) \\
\end{array}$ & $\begin{array}{l}10 \\
(33.3 \%)\end{array}$ & \multirow{4}{*}{0.51} & \multirow{4}{*}{0.96} & \multirow{4}{*}{0.49} & \multirow{4}{*}{0.57} \\
\hline & Farmer & $\begin{array}{l}4 \\
(28.6 \%) \\
\end{array}$ & $\begin{array}{l}47 \\
(35.6 \%) \\
\end{array}$ & $\begin{array}{l}20 \\
(31.7 \%) \\
\end{array}$ & $\begin{array}{l}8 \\
(26.7 \%) \\
\end{array}$ & & & & \\
\hline & Worker & $\begin{array}{l}7 \\
(50 \%)\end{array}$ & $\begin{array}{l}51 \\
(38.6 \%)\end{array}$ & $\begin{array}{l}20 \\
(31.7 \%)\end{array}$ & $\begin{array}{l}11 \\
(36.7 \%)\end{array}$ & & & & \\
\hline & Others & $\begin{array}{l}1 \\
(7.1 \%)\end{array}$ & $\begin{array}{l}4 \\
(3 \%)\end{array}$ & 0 & $\begin{array}{l}1 \\
(3.3 \%)\end{array}$ & & & & \\
\hline \multicolumn{2}{|c|}{ Smoking } & $\begin{array}{l}4 \\
(26.7 \%)\end{array}$ & $\begin{array}{l}48 \\
(36.4 \%)\end{array}$ & $\begin{array}{l}24 \\
(38.1 \%)\end{array}$ & $\begin{array}{l}7 \\
(23.3 \%)\end{array}$ & 0.45 & 0.78 & 0.50 & 0.99 \\
\hline \multicolumn{2}{|c|}{$\begin{array}{ll}\text { Duration of current } \\
\text { marriage (years) }\end{array}$} & $5.43 \pm 2.34$ & $5.65 \pm 4.46$ & $5.59 \pm 3.74$ & $4.03 \pm 2.09$ & 0.23 & 0.77 & 0.84 & 0.07 \\
\hline \multicolumn{2}{|c|}{$\begin{array}{lll}\begin{array}{l}\text { Family } \\
\text { infertility }\end{array} & \text { history of }\end{array}$} & $\begin{array}{l}1 \\
(7.1 \%)\end{array}$ & $\begin{array}{l}10 \\
(7.6 \%)\end{array}$ & $\begin{array}{l}3 \\
(4.8 \%)\end{array}$ & $\begin{array}{l}2 \\
(6.7 \%)\end{array}$ & 0.91 & 0.64 & 0.86 & 0.94 \\
\hline
\end{tabular}

$* \mathrm{P}$ value $<0.05$ was considered significant. 
P1: between azoospermia positive deletion and azoospermia negative deletion.

$\boldsymbol{P 2}$ : between azoospermia positive deletion and oligozoospermia negative deletion.

P3: between azoospermia positive deletion and normozoospermia negative deletion.

\section{Clinical and laboratory data:}

In the infertile men; the mean volume $\pm \mathrm{SD}$ of the right testis was $11.79 \pm 2.85 \mathrm{ml}$ and that of the left testis was $10.87 \pm 2.87 \mathrm{ml}$. The mean serum level $\pm \mathrm{SD}$ of hormones were FSH $(21.89 \pm 10.23 \mathrm{mIU} / \mathrm{ml}), \mathrm{LH}(14.12 \pm 6.19 \mathrm{mIU} / \mathrm{ml})$, testosterone $(5.60 \pm$ $1.37 \mathrm{ng} / \mathrm{ml})$, and prolactin $(6.88 \pm 1.60 \mathrm{ng} / \mathrm{ml})$. The clinical and laboratory data in the infertile men groups as well as control group are shown in table 2.

Table 2: Clinical and laboratory data in the study population.

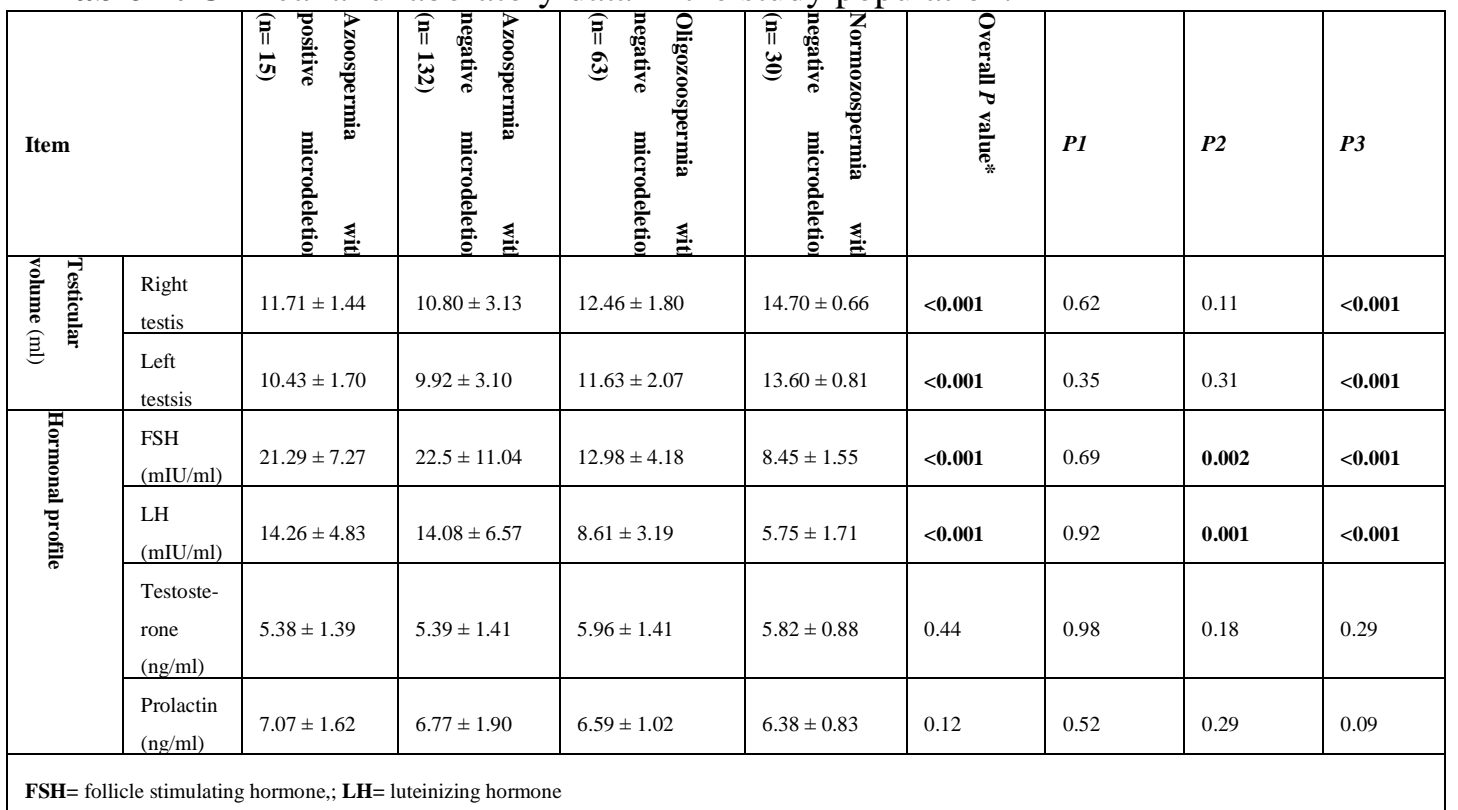

* P value $<0.05$ was considered significant.

P1: between azoospermia positive deletion and azoospermia negative deletion.

P2: between azoospermia positive deletion and oligozoospermia negative deletion.

P3: between azoospermia positive deletion and normozoospermia negative deletion.

\section{Results of PCR:}

Regarding the examination of Y chromosome microdeletions; deletions were found in 15 of the 210 infertile patients $(7.14 \%)$. AZFc deletion was found in 3 of the 210 infertile patients $(1.4 \%)$, b2/b3 deletion in $1(0.48 \%)$ and $\mathrm{gr} / \mathrm{gr}$ deletion in $11(5.24 \%)$ of infertile patients. No deletion was found in the fertile normozoospermic men.Only one case of $\mathrm{gr} / \mathrm{gr}$ deletion was found in oligozoospermic men $(1.56 \%)$. Out of the 146 azoospermic men; $3(2.05 \%)$ had complete AZFc deletion, $1(0.69 \%)$ had b2/b3 deletion, and $10(6.85 \%)$ had gr/gr deletion.

The age of oligozoospermic man with gr/gr deletion was 24 years, testicular volume was $13 \mathrm{ml}$ bilaterally, sperm concentration was $2 \mathrm{million} / \mathrm{ml}$, and hormonal levels were FSH $(13.6 \mathrm{mIU} / \mathrm{ml}), \mathrm{LH}(8.6 \mathrm{mIU} / \mathrm{ml})$, total testosterone $(6.4 \mathrm{ng} / \mathrm{ml})$, and prolactin $(7.2 \mathrm{ng} / \mathrm{ml})$.

\section{DISCUSSION}

Microdeletions of $\mathrm{Y}$ chromosome are the second most frequent genetic cause of male infertility after Klinefelter syndrome $^{(5)}$.A correlation between $\mathrm{Y}$ chromosome deletions in AZF regions and male infertility was first 
documented in $1976^{(\mathbf{1 9})}$.Partial AZFc deletions were identified, with gr/gr deletion as the most common ${ }^{(\mathbf{1 2})}$. The effect of the deletion is largely dependent on the ethnic and geographic origin of the study population ${ }^{(11)}$.

In the current study; microdeletions were found in $7.14 \%$ of infertile men, which is less than that previously reported in Egyptian studies; $12 \%{ }^{(\mathbf{1 3})}$, $37 \%^{(\mathbf{1 4})}, 20.4 \%^{(15)}$, and $10.3 \%^{(16)}$. These differences may be related to different inclusion criteria, sample size and the used technique.

Complete AZFc deletion was found in $1.4 \%$ of the infertile population. This was near that previously reported in Germany $(1 \%)^{(\mathbf{2 0})}$, South Iran $(1.25 \%)^{(21)}$, and India $(0.97 \%)^{(22)}$. This rate was less than previously reported in Egyptian studies; 6\% $\%^{(\mathbf{1 3})}$, and $9.2 \%^{(\mathbf{1 5})}$. Higher prevalence was also reported from other studies; 7.4 in a Han-Chinese population ${ }^{(23)}$, and $9.17 \%$ in Dravidian-Indian ${ }^{(24)}$.

In the present study; partial AZFc deletions were found in $5.7 \%$ of infertile men, with $\mathrm{gr} / \mathrm{gr}$ deletion in $5.24 \%$ and b2/b3 deletion in $0.48 \%$. This in accordance with a previous study from

Northern Italy that reported partial deletions in $5.2 \%$ of infertile men with $\mathrm{gr} / \mathrm{gr}$ deletions in $5 \%$ and b2/b3 deletions in $0.2 \%{ }^{(25)}$. Another study reported partial

deletions in $6.2 \%$ of infertile men in China with $\mathrm{gr} / \mathrm{gr}$ deletions in $5.84 \%$ and b2/b3 deletions in $0.24 \%{ }^{(22)}$.Similar prevalences of $\mathrm{gr} / \mathrm{gr}$ deletions were previously reported:4.8\% in Gaza StripPalestine area ${ }^{(26)}, 4.2 \%$ in Spain ${ }^{(27)}$, and $5 \%$ of infertile men in South $\operatorname{Iran}^{(21)}$.

Higher prevalence were previously reported: $\mathrm{gr} / \mathrm{gr}$ deletions in $9.2 \%$ of infertile Egyptian men ${ }^{(\mathbf{1 5})}$, gr/gr deletions in $12.5 \%$ and $\mathrm{b} 2 / \mathrm{b} 3$ deletion in $9.3 \%$ in China ${ }^{(23)}$, gr/gr deletions in $7.2 \%$ and $\mathrm{b} 2 / \mathrm{b} 3$ deletions in $1.4 \%$ of infertile Indian men ${ }^{(28)}$, gr/gr deletions in $8.5 \%$ and $\mathrm{b} 2 / \mathrm{b} 3$ deletions in $5.8 \%$ of infertile Korean men ${ }^{(29)}$, gr/gr deletions in $10 \%$ and $\mathrm{b} 2 / \mathrm{b} 3$ deletions in $5 \%$ of infertile men from $\operatorname{Iran}^{(30)}, \mathrm{gr} / \mathrm{gr}$ deletions in $6.25 \%$ and $\mathrm{b} 2 / \mathrm{b} 3$ deletions in $7.21 \%$ in Dravidian-Indians ${ }^{(24)}$, and $\mathrm{gr} / \mathrm{gr}$ deletions in $12.4 \%$ and $\mathrm{b} 2 / \mathrm{b} 3$ deletions in $4.96 \%$ of infertile Chinese men ${ }^{(31)}$.

Rozenand colleagues reported gr/gr deletions in $2.4 \%, \mathrm{~b} 2 / \mathrm{b} 3$ deletion in $1.1 \%$, and $\mathrm{b} 1 / \mathrm{b} 3$ in $0.1 \%$ of the studied populations from five different locations (India, Poland, Tunisia, United States and Vietnam) ${ }^{(32)}$. A previous study documented $\mathrm{gr} / \mathrm{gr}$ deletion in $3.2 \%$ and $b 2 / b 3$ deletion in $0.5 \%$ of infertile men in Italy ${ }^{(33)}$. Another study documented gr/gr deletion in $3.9 \%$ and $b 2 / b 3$ deletion in $1.3 \%$ of infertile men in Spain ${ }^{(\mathbf{3 4})}$.

In the current study; no deletions were recorded in the normozoospermic control group. This is in accordance with previous studies ${ }^{(12,15,27,35)}$. Other studies reported partial AZFcsubdeletions in the control groups $\left(\mathbf{2 1}, \mathbf{2 4}, \mathbf{2 8 - 3 1},{ }^{36}\right)$. The variation in the frequency may be related to ethnic variation, genetic background and $\mathrm{Y}$ haplotypes. The discovery of specific haplogroups with an increased propensity for the occurrence of partial $\mathrm{AZFc}$ deletions may explain differences in the frequencies of partial AZFc deletions between populations ${ }^{(7)}$.

In the current study; there was significant difference in testicular volume between patients with AZF deletions and normozoospermic men. However; there was no significant difference in testicular volume between azoospermicpatients with AZF deletions and azoospermic men without deletions. This is in accordance with previous report ${ }^{(\mathbf{1 6})}$. This finding implied that AZF microdeletions in infertile patients are not related to the testicular volume. 
In the current study; in spite of significant difference between men with AZF deletions and normozoospermic men in the levels of FSH and LH; there was no significant difference between the levels of reproductive hormones (FSH, LH, testosterone and prolactin) in azoospermic men with and without AZF deletions. These findings are in accordance with previous studies (16, 20, 24, 37, 38). These results implied that AZF microdeletions in infertile patients were not be related to the levels of FSH, $\mathrm{LH}$ and testosterone.

To the contrary; in a previous study; the concentrations of FSH and testosterone in patients with microdeletion were significantly lower than those without microdeletions, while concentration of LH was significantly higher in patients with microdeletions ${ }^{(39)}$. This may be related to inclusion of patients with hypogonadotrophichypogonadism and chromosomal abnormalities who were excluded from the current study.

This study provides further evidence that partial deletions of the AZFc region are a risk factor for decreased sperm quality. Several partial deletions of AZFc were found to be associated with impaired spermatogenesis, suggesting multiple genes related to this process are located in this region. These findings reinforce the necessity of AZF microdeletion testing among infertile males prior to employment of assisted reproduction techniques.

There were some limitations to this study. Small number of normozoospermic men was examined due to difficulties in enrollment. The Y haplogroups in the study population and gene dosage in AZF regions were out of the scope of this study. No germline analyses were performed to determine if the deletions were inherited, somatic, or mosaic mutations. Further studies are warranted to overcome these limitations.

\section{REFERENCES}

1. Venkatesh T, Suresh PS and Tsutsumi R: New insights into the genetic basis of infertility.Appl Clin Genet. 2014; 7 : $235-43$.

2. Inhorn MC and Patrizio P: Infertility around the globe: new thinking on gender, reproductive technologies and global movements in the $21 \mathrm{st}$ century.Hum Reprod Update. 2015; 21(4): 411-26.

3. Stuppia L, Franzago M, Ballerini P, Gatta V and Antonucci I: Epigenetics and male reproduction: the consequences of paternal lifestyle on fertility, embryo development, and children lifetime health.Clin Epigenetics. 2015; 7: 120.

4. Hotaling $\mathbf{J}$ and Carrell DT: Clinical genetic testing for male factor infertility: current applications and future directions.Andrology. 2014; 2(3): $339-50$.

5. Calafell F and Larmuseau MHD: The Y chromosome as the most popular marker in genetic genealogy benefits interdisciplinary research.Hum Genet. 2017; 136(5): 559-73.

6. Skaletsky H, Kuroda-Kawaguchi T, Minx PJ, Cordum HS, Hillier L, Brown LG, Repping S, Pyntikova T, Ali J, Bieri T, Chinwalla A, Delehaunty A, Delehaunty K, Du H, Fewell G, Fulton L, Fulton R, Graves T, Hou SF, Latrielle P, Leonard S, Mardis E, Maupin R, Mcpherson J, Miner T, Nash $W$, Nguyen $C$, Ozersky P, Pepin K, Rock S, Rohlfing T, Scott K, Schultz B, Strong C, TinWollam A, Yang SP, Waterston RH, Wilson RK, Rozen S and Page DC: The male-specific region of the human $\mathrm{Y}$ chromosome is a mosaic of discrete sequence classes.Nature. 2003; 423(6942): 825-37.

7. Krausz $\mathrm{C}$ and Casamonti E: Spermatogenic failure and the $\mathrm{Y}$ chromosome.Hum Genet. 2017; 136(5): 637-655. 
8. Li Z, Haines CJ and Han Y: "Microdeletions" of the human Y chromosome and their relationship with male infertility.J Genet Genomics. 2008; 35(4): 193-9.

9. Malekasgar AM and Mombaini $\mathrm{H}$ : Screening of ' $\mathrm{Y}$ ' chromosome microdeletions in Iranian infertile males.J Hum Reprod Sci. 2008; 1(1): 29.

10. Suganthi R, Vijesh VV, Vandana $N$ and Fathima Ali Benazir J: Y choromosomal microdeletion screening in the workup of male infertility and its current status in India.Int J Fertil Steril. 2014; 7(4): 253-66.

11. Krausz C, Hoefsloot L, Simoni M and Tuttelmann F: EAA/EMQN best practice guidelines for molecular diagnosis of Y-chromosomal microdeletions: state-of-the-art 2013.Andrology. 2014; 2(1): 5-19.

12. Repping S, Skaletsky H, Brown L, Van Daalen SK, Korver CM, Pyntikova T, Kuroda-Kawaguchi T, De Vries JW, Oates RD, Silber S, Van Der Veen F, Page DC and Rozen S: Polymorphism for a 1.6-Mb deletion of the human $\mathrm{Y}$ chromosome persists through balance between recurrent mutation and haploid selection.Nat Genet. 2003; 35(3): 247-51.

13. El Awady MK, El Shater SF, Ragaa E, Atef K, Shaheen IM and Megiud NA: Molecular study on Y chromosome microdeletions in Egyptian males with idiopathic infertility.Asian $J$ Androl. 2004; 6(1): 53-7.

14. Elhawary N, Seif-Eldin N, Zaki M, Diab H, Teama $S$ and Saleh S: Common Tag STSs in the AZF region associated with azoospermia and severe oligospermia in infertile Egyptian men.Open Androl J. 2010; 2(1): 11-8.

15. Fayez A, El-Sayed A, El-Desouky M, Zarouk W, Kamel A, Fahmi I and ElRuby M: Molecular characterization of some genetic factors controlling spermatogenesis in Egyptian patients with male infertility. Int $J$ Infertility Fetal Med. 2012; 3(3): 69-77.

16. Hussein TM and Elneely DI: Ychromosome microdeletions and the MTHFR C677T polymorphism in Egyptian men with nonobstructive azoospermia.Hum Androl. 2014; 4(3): 66-70.

17. Silber SJ: The $Y$ chromosome in the era of intracytoplasmic sperm injection: a personal review.Fertil Steril. 2011; 95(8): 2439-48.e1-5.

18. World Health Organization: WHO Laboratory Manual for the Examination and Processing of Human Semen, 5th Edition.WHO Press, Geneva, Switzerland. 2010.

19. Tiepolo $L$ and Zuffardi O: Localization of factors controlling spermatogenesis in the nonfluorescent portion of the human $\mathrm{Y}$ chromosome long arm.Hum Genet. 1976; 34(2): 11924.

20. Simoni M, Tuttelmann F, Gromoll J and Nieschlag E: Clinical consequences of microdeletions of the Y chromosome: the extended Munster experience.Reprod Biomed Online. 2008; 16(2): 289-303.

21. Masoudi R, Mazaheri-Asadi $L$ and Khorasani S: Partial and complete microdeletions of $\mathrm{Y}$ chromosome in infertile males from South of Iran.Mol Biol Res Commun. 2016; 5(4): 247-255.

22. Bansal SK, Jaiswal D, Gupta N, Singh K, Dada R, Sankhwar SN, Gupta G and Rajender S: Gr/gr deletions on Y-chromosome correlate with male infertility: an original study, meta-analyses, and trial sequential analyses.Sci Rep. 2016; 6: 19798.

23. Lu C, Zhang J, Li Y, Xia Y, Zhang F, Wu B, Wu W, Ji G, Gu A, Wang S, Jin $L$ and Wang $X$ : The $b 2 / b 3$ subdeletion shows higher risk of spermatogenic failure and higher frequency of complete $\mathrm{AZFc}$ deletion than the gr/gr subdeletion in a Chinese population.Hum Mol Genet. 2009; 18(6): 1122-30. 
24. Vijesh VV, Nambiar V, Mohammed SI, Sukumaran $S$ and Suganthi R: Screening for AZFc partial deletions in Dravidian men with nonobstructive azoospermia and oligozoospermia.Genet Test $\mathrm{Mol}$ Biomarkers. 2015; 19(3): 150-5.

25. Ferlin A, Tessari A, Ganz F, Marchina E, Barlati S, Garolla A, Engl $B$ and Foresta C: Association of partial AZFc region deletions with spermatogenic impairment and male infertility.J Med Genet. 2005; 42(3): 209-13.

26. Shaqalaih AJ, Abu Halima MS, Ashour MJ and Sharif FA: Screening for $\mathrm{Y}$-chromosome microdeletions in a population of infertile males in the Gaza Strip.J Exp Clin Assist Reprod. 2009; 6: 7.

27. De Llanos M, Ballesca JL, Gazquez C, Margarit E and Oliva R: High frequency of $\mathrm{gr} / \mathrm{gr}$ chromosome $\mathrm{Y}$ deletions in consecutive oligospermic ICSI candidates.Hum Reprod. 2005; 20(1): 216-20.

28. Shahid M, Dhillon VS, Khalil HS, Sexana $A$ and Husain SA: Associations of Y-chromosome subdeletion gr/gr with the prevalence of Y-chromosome haplogroups in infertile patients.Eur J Hum Genet. 2011; 19(1): 23-9.

29. Choi J, Song SH, Bak CW, Sung SR, Yoon TK, Lee DR and Shim SH: Impaired spermatogenesis and $\mathrm{gr} / \mathrm{gr}$ deletions related to $\mathrm{Y}$ chromosome haplogroups in Korean men.PLoS One. 2012; 7(8): e43550.

30. Motovali-Bashi $M$, Rezaei $Z$, Dehghanian $\mathbf{F}$ and Rezaei $\mathbf{H}$ : Multiplex PCR based screening for micro/partial deletions in the AZF region of $\mathrm{Y}$-chromosome in severe oligozoospermic and azoospermic infertile men in Iran.Iran J Reprod Med. 2015; 13(9): 563-70.
31. Wang YM, Li Q, Song LB, Zhang JY, Yang $J$ and Song NH: [Association of the deleted DAZ gene copy related to gr/gr and b2/b3 deletions with spermatogenic impairment].Zhonghua Nan Ke Xue. 2016; 22(1): 17-21.

32. Rozen SG, Marszalek JD, Irenze K, Skaletsky H, Brown LG, Oates RD, Silber SJ, Ardlie $K$ and Page DC: AZFc deletions and spermatogenic failure: a population-based survey of 20,000 Y chromosomes.Am J Hum Genet. 2012; 91(5): 890-6.

33. Giachini C, Laface I, Guarducci E, Balercia G, Forti $G$ and Krausz C: Partial AZFc deletions and duplications: clinical correlates in the Italian population.Hum Genet. 2008; 124(4): 399-410.

34. Lo Giacco D, Chianese C, SanchezCurbelo J, Bassas L, Ruiz P, Rajmil O, Sarquella J, Vives A, Ruiz-Castane E, Oliva R, Ars E and Krausz C: Clinical relevance of $\mathrm{Y}$-linked $\mathrm{CNV}$ screening in male infertility: new insights based on the 8-year experience of a diagnostic genetic laboratory.Eur $J$ Hum Genet. 2014; 22(6): 754-61.

35. Bunyan DJ, Callaway JL and Laddach N: Detection of Partial Deletions of Y-chromosome AZFc in Infertile Men Using the Multiplex Ligation-dependent Probe Amplification Assay.J Reprod Infertil. 2012; 13(3): 174-8.

36. Stahl PJ, Mielnik A, Margreiter M, Marean MB, Schlegel PN and Paduch DA: Diagnosis of the gr/gr Y chromosome microdeletion does not help in the treatment of infertile American men.J Urol. 2011; 185(1): 233-7.

37. Liu W, Gao X, Ma G, Yan L, Chen T, Li T, Yu RM and Ma JL: Correlation of genetic results with testicular histology, hormones and sperm retrieval in nonobstructive azoospermia patients with testis biopsy.Andrologia. 2016. 
SOHAG MEDICAL JOURNAL

Vol. 21 No.2 July 2017

38. Zhang YS, Dai RL, Wang RX, Zhang ZH, Fadlalla $E$ and Liu RZ: Azoospermia factor microdeletions: occurrence in infertile men with azoospermia and severe oligozoospermia from China.Andrologia. 2014; 46(5): 535-40.
Y-Chromosome Microdeletion Analysis Ashraf A. Abd El-Latif.et al

39. Abid S, Maitra A, Meherji P, Patel Z, Kadam S, Shah J, Shah R, Kulkarni V, Baburao V and Gokral J: Clinical and laboratory evaluation of idiopathic male infertility in a secondary referral center in India.J Clin Lab Anal. 2008; 22(1): 29-38. 